\title{
A história do trabalho das mulheres no Brasil: perspectiva feminista
}

\author{
The history of women's work in Brazil: \\ a feminist perspective
}

\author{
La historia del trabajo de las mujeres en Brasil: \\ perspectiva feminista
}

OS DIREITOS DAS MULHERES: FEMINISMO E TRABALHO NO BRASIL (1917-1937). Fraccaro G. Rio de Janeiro: Associação Brasileira de Estudos do Trabalho/Editora FGV; 2018. 236 p. ISBN 978-85-22520-80-0.

doi: 10.1590/0102-311X00225318

Este livro foi vencedor do prêmio concedido pela Associação Brasileira de Estudos do Trabalho (ABET) em 2017. Glaucia Fraccaro, por meio de uma análise histórica brasileira (1917 a 1937), proporciona ao(à) leitor(a) o conhecimento das origens da legislação e dos direitos trabalhistas, bem como das contradições sociais, políticas e econômicas da situação de vida e de trabalho, sobretudo das mulheres naquele período.

Na primeira parte do livro, com três capítulos, a autora mostra que, durante o período estudado, a maioria de trabalhadores(as) pertencia à área rural, com baixa escolaridade e qualificação. De maneira geral, reitera as dificuldades diante do enfrentamento das desigualdades de gênero no trabalho, bem como os movimentos para a garantia dos direitos das mulheres enquanto trabalhadoras da esfera produtiva. Os dados e as análises desse período mostram o processo de industrialização e a baixa participação feminina no mercado de trabalho. Mas, ao mesmo tempo, um aumento na alfabetização das mulheres, sendo que os postos destinados a elas eram especial- mente as áreas de ensino, artes e do comércio em geral. Havia diferenças de salários entre homens e mulheres, em um momento histórico em que eles ganhavam mais e estavam em postos de trabalho mais qualificados, ao passo que o trabalho doméstico e de cuidado estava sob a responsabilidade especialmente delas.

É na interlocução com as precárias condições de trabalho que vão sendo analisados as jornadas exaustivas (até 16 horas por dia), a baixa participação sindical das mulheres, os acidentes graves de trabalho, a exploração da mão de obra infantil, a fome, dentre outros. Nesse cenário, as greves estavam postas e, em alguns casos, foram repreendidas pelo aparato policial da época. O movimento grevista de 1917 tinha como reivindicações: a diminuição da jornada para oito horas diárias, a proibição do trabalho de crianças menores de 14 anos e de atividades noturnas, a igualdade de direitos para homens e mulheres, os direitos da maternidade, o aumento de salário e as reparações para os acidentes de trabalho. Ressaltam-se também as reivindicações das mulheres contra os abusos dos empregadores e funcionários. As greves dos anos de 1930 caracterizaram-se pela exclusão e embates das mulheres nas pautas sindicais, com maior visibilidade para as condições de trabalho dos homens, o que é desenvolvido de maneira aprofundada no livro.

Os movimentos feministas abordados tinham como centralidade a perspectiva do direito ao sufrágio, mas também os esforços pela 
igualdade entre homens e mulheres no trabalho: os exercícios profissional e da maternidade não deveriam repercutir desfavoravelmente na vida das mulheres. Por meio de sua análise, é possível compreender os movimentos feministas e a sua relação com a classe social e seus diferentes campos de disputa: "contar a história do feminismo por seus grupos hegemônicos foi uma estratégia narrativa que escondeu os conflitos a ponto de escamotear tudo aquilo que as trabalhadoras pensavam sobre a sua condição" (p. 85).

A segunda parte, desenvolvida por meio de três capítulos, versa sobre a maternidade e os direitos das mulheres. São analisadas as violências do trabalho infantil e as proteções para o trabalho das mulheres. Por meio da legislação do Estado de São Paulo, em 1918, as mulheres não deveriam trabalhar quatro semanas antes e depois do parto. No entanto, essa proteção às mulheres e aos seus filhos não foi colocada em prática pelas autoridades e/ou pelos empresários da época. As imbricações e os conflitos entre o trabalho assalariado e o de cuidado de filhos e/ ou família (disponibilidade de creches, horários para amamentação, licença em caso de abortos, escolas maternais, dentre outros) são analisados à medida da garantia da efetivação de direitos trabalhistas às mulheres e à segurança e saúde de seus filhos.

A argumentação sobre as influências internacionais no cenário da vida de brasileiras é colocada com as contribuições das ações da Organização Internacional do Trabalho (OIT). Havia, nessa época, a preocupação internacional com as condições de trabalho e de saúde das mulheres e também com a sobrecarga de atividades no âmbito doméstico. O excesso de trabalho, o contato com os produtos químicos e a proteção à maternidade foram pautas centrais na $1 \underline{a}$ Conferência Internacional do Trabalho, que previu a licença gestante entre as seis semanas antes e depois do nascimento. Os direitos trabalhistas da maternidade também perpassaram pela garantia de locais adequados para amamentação, licença remunerada, atendimentos de saúde para gestantes e outros.
Assim, a autora discute o cenário político e social internacional que, por um lado, apresentava as contradições de ser trabalhadora e, por outro, os avanços para a igualdade no trabalho, com direitos relativos à permanência no mercado de trabalho e também ao cuidado familiar. Aponta as reivindicações do movimento feminista para a inserção das mulheres na OIT e na atuação dos sindicatos.

A última parte - dividida em dois capítulos discute a legislação e a igualdade das mulheres. Nesse sentido, há de se considerar que as "condições legais também organizam a hierarquia entre mulheres e homens a moldar noções de direito e cidadania" (p. 169). É, sobretudo, a partir disso, que a autora analisa o voto feminino a despeito das restrições dos direitos políticos das mulheres em uma sociedade patriarcal, na qual a submissão ao poder masculino se fez presente até mesmo no âmbito legislativo. É por meio da análise do Decreto do Trabalho das Mulheres (datado de 1932) que se colocam, no centro do debate, a igualdade salarial para homens e mulheres, a licença maternidade, a proibição do trabalho noturno, o afastamento em casos de aborto, a proibição de dispensa por gravidez, a licença gestante - quatro semanas antes do parto e depois dele, dentre outros. É interessante perceber que, desde os primórdios dos movimentos feministas pelos direitos à dignidade no trabalho, a questão da divisão sexual do trabalho está posta. Para Hirata \& Kergoat 1 , a divisão sexual do trabalho expõe, além das desigualdades entre homens e mulheres, o trabalho doméstico e reprodutivo desempenhado gratuitamente e, sobretudo, pelas mulheres na sociedade capitalista.

No último capítulo, são trazidas à discussão as exigências dos aspectos morais e dos comportamentos adequados das mulheres para a inserção e permanência no trabalho produtivo. Ou seja, a adequada conduta, os bons comportamentos relacionados com as representações de mulheres como cuidadosas e o apreço pela honra foram requeridos na esfera da produção. Com isso, a proibição do trabalho no período noturno não foi de pronto aceita pelo movimento feminista, já 
que restringia as atividades das mulheres apenas aos setores permitidos no Decreto de 1932. Após o ano de 1937, com a ditadura instaurada no governo de Getúlio Vargas, a diminuição do salário mínimo das mulheres estava posta. Esse cenário influenciou a vida delas, acentuando a noção do cuidado e bem-estar familiar como centrais e de responsabilidade das mulheres.

O mérito deste livro está na minúcia das análises das estreitas ligações do trabalho de mulheres, a maternidade e o cuidado familiar com o desenvolvimento do feminismo brasileiro. Por meio das categorias gênero e classe social, são evidenciadas as mobilizações sociais e de organismos internacionais e suas contradições da efetividade dos direitos trabalhistas para mulheres no Brasil. Embora a categoria de raça/etnia não tenha sido aprofundada, a obra proporciona subsídios para o avanço da temática, a fim de compreender, desde o início do século passado, as precárias condições de trabalho de mulheres, a gratuidade do trabalho realizado na esfera da reprodução, a hierarquização e as desigualdades salariais entre homens e mulheres, os movimentos sociais e políticos para a autonomia daquelas que contribuíram, pelo exercício do trabalho, com o desenvolvimento do país.

Sendo assim, concorda-se com Federici 2 quando argumenta que, embora Marx não tenha se debruçado em uma teoria feminista, é capaz de trazer contribuições do materialismo histórico dialético para a crítica do trabalho reprodutivo das mulheres e a sua não remuneração, além das explorações da classe trabalhadora na atualidade. Federeci considera as análises de gênero primordiais para a compreensão do desenvolvimento do capitalismo, o que Fraccaro realiza ao longo de sua obra. Desse modo, instiga a pensar de como, passados cem anos, ainda se tem como norte as reivindicações por trabalhos dignos e saudáveis, além de evidenciar as explorações nas quais estão submetidas muitas trabalhadoras em uma sociedade desigual: "nessa matéria, tudo muda, mas nada muda" 1 (p. 597).

\section{Cristiane Batista Andrade 1}

\author{
1 Escola Nacional de Saúde Pública Sergio Arouca, Fundação \\ Oswaldo Cruz, Rio de Janeiro, Brasil. \\ cristianeandrade@fiocruz.br
}

\section{Informação adicional}

ORCID: Cristiane Batista Andrade (0000-00031441-9171).

1. Hirata H, Kergoat D. Novas configurações da divisão sexual do trabalho. Cad Pesqui 2007; 37:595-609.

2. Federici S. Marx and feminism. TripleC 2018; $16: 468-75$
Recebido em 24/Nov/2018

Versão final reapresentada em 13/Dez/2018

Aprovado em 27/Dez/2018 